\title{
チーム医療の実践〜チームが機能するため に…医師への期待〜
}

\section{「あなたは, チームの危機を救う患者やスタッ フの『声』に耳を傾け，応えていますか?」}

\section{樋口敦子}

〔日内会誌 $103 ： 1712 \sim 1723 ， 2014 〕$

Key words チーム医療, チームSTEPPS, チームトレーニング

はじめに

患者安全を確保するためチーム医療の推進の 取り組みが行われている。 チームの重要な存在 である医師には，豊富な専門知識と技術と能力 を身に付け，その仕事を忠実に果たそうとする からこそ持つ職業観と強みがある. 医師にしか できない，医師だからこそできる役割があり， チームが機能するための要としての期待は大き い. 医師には, 診療・治療方針の判断や決定な ど, 患者や多職種から常に重大な意思決定と責 任を求められる.ひとりで思い悩む日々の連続, その重圧は計り知れない. しかし，「先生，あな たはひとりではない」. あなたの周りには, 多職 種で構成されたチームがいる. チームで取り組 むことで，より安全でより最善の医療の提供が
可能になる.チームの一員であることをもっと 意識してほしい.

私は, 国立保健医療科学院での約半年間の医 療安全管理者研修をはじめ, 多くの方々にご指 導いただきながら, 多くの医療専門職種, 学生, 開業薬局，企業などを対象に“チームSTEPPS” (Team Strategies and Tool to Enhance Performance and Patient Safety : 米国で開発された 医療の質, 安全, 効率を改善するエビデンスに 基づいたチームワークシステム) ${ }^{11}$ のチームトレー ニングを行ってきた.この体験をもとに, 看護 職の立場からチームを動かす重要な存在である 医師に，理解し，共に取り組んでほしいことを 述べる。

(なお,このチームSTEPPSの概要は本学会誌 にも掲載され 2) $^{2}, 2013$ 年度から, 試行的に内科専 門医部会事業でワークショップが開催されてい

立川メディカルセンター立川綜合病院

Series : For Attending Physicians ; Seeking to Understand the Diversity of Medicine ; How to work as a team-Expectations to doctors to make our team function better. "Are you really listening to your patients and team members and responding to them in order to save them from crises".

Atsuko Higuchi : Tachikawa Medical Center Tachikawa General Hospital, Japan. 
ると聞いている.)

1.あなたは患者の命を守るため, いつで も誰にでも疑義・懸念を言えますか?

研修の始まりに，チームワークの欠如による コミュニケーションエラーにより発生した医療 事故の被害者家族のメッセージ動画（チーム STEPPS教材)を見ていただいた後, この質問を している.この動画では「ミスは一人の責任で はないが, もし誰かが気付き, 行動を起こして いれば，悲劇を防げていたかもしれない」とい う家族の願いが語られている. しかし，この質 問をしても, 職種や経験年数, 職場に関係なく ほとんどの参加者が手を挙げない. 複数の人の 中で気付いた少数が発言すれば誰かの命を守る ことが可能になる場合もある，種田は，医療事 故は多くの場合, システムに問題がありチーム として機能しなかった最悪のケースであると述 べている3 . チーム医療の推進と言いながら, 私 たちは，本当にチームとして機能できているの だろうか?チームとして機能するためにはどう したらいいのだろうか?

\section{2. チームトレーニングは必要か?}

医療は, 多くの専門職集団で支えられ, 複数 の職種，複数の「人」の手を介して時間と空間 を経て患者に提供される.「人」が行う作業であ るため, ヒューマンエラーは免れない。 また,

職種, 経験, 知識, 世代の違いや権威勾配が存 在するうえに, 様々な業務が同時進行し, 突発 的で, しかも危機的な割り込み業務も発生する. そこでは, 短時間で端的な伝達, 具体的な指示 の省略, 掗互い分かっただろうという思い込み などコミュニケーションエラーが発生しやすい 状況に追い込まれる.

医療事故の多くは，コミュニケーションの障
害などでチームが実質的に機能しない，チーム ワークの欠如から発生すると言われる。 チーム エラーはコミュニケーションエラーである ${ }^{3)}$. 私 たち看護師は, 患者の変化に気付き, チームに 伝える発信者であり，様々な職種が関連したプ

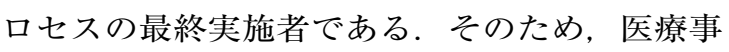
故当事者になることがある. 多くは, 薬郕が関 連しており, 複数の医師・薬剂師・看護師が関 わるためエラーが発生しやすく，患者に及ぼす 影響も大きい. しかし, 複数の専門職種が関わ るからこそ, ヒューマンエラーを補いミスに気 付くチャンスもあり, チーム力を活かして医療 安全対策に取り組めばリスクを減らすことも可 能である。

チーム力を活かし医療スタッフ間で連携・補 完を推進するには, チームパフォーマンスを高 め「チームとして協働するためのスキル」をメ ンバー全員が身に付ける必要がある。しかし, このスキルは, 多くの者が生来持っている能力 ではないにもかかわらず, これまで訓練する機 会は少なかった．患者の安全を守るためには, 多職種専門家集団チーム力の最大限の発揮に向 けて, 専門職としての「個」のテクニカルスキ ルとチームとして協働するためのスキル（ノン テクニカルスキル）をトレーニングし育成する 取り組みが必要である.

“チームSTEPPS”(図 1) は, 米国で開発され たチームパフォーマンスを上げるエビデンスに 基づいたチームトレーニングプログラムとして 推進されている3).“チームSTEPPS”では, チー ムを「共通の目標に向けて, 適宜に適応性をもっ て相互協力しあう 2 人以上の人間の集まりであ り，それぞれが特定の役割または機能を持ち, 期間限定で参加している」4) と定義し，さらに, 「有能なチームメンバーは他のチームメンバーが 必要としているものを予測する能力が高く, 適 切な情報・フィードバックを提供し，レベルの 高い意志決定を行い, 対立があればうまく対応 


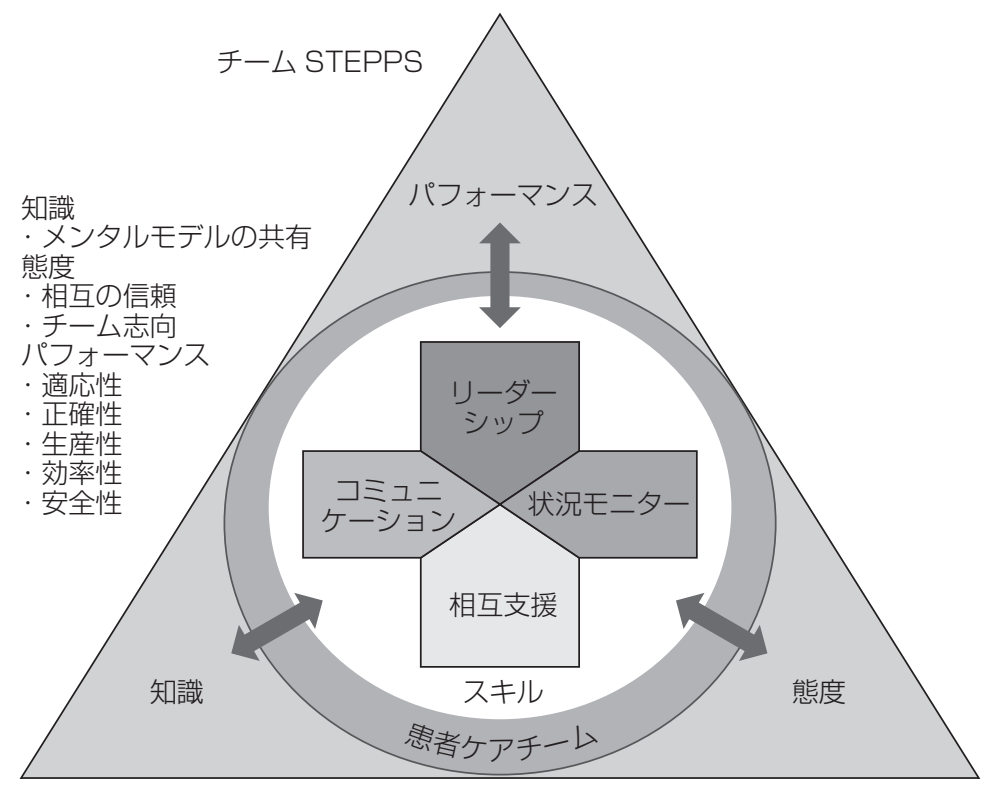

図 1. チームコンピテンシーの枠組みとアウトカム ${ }^{3)}$

し, 自分の役割・責任を理解し, 個人のパフォー マンスを向上させてチーム全体にかかるストレ スを軽減する」4)としている。この医療チームの メンバーが, 4 つのコンピテンシー(リーダーシッ プ・状況モニター・相互支援・コミュニケーショ ン)を実施することで,【知識】態度】【゚フォー マンス】の 3 つの側面からアウトカムが得られ るとし，4つのコンピテンシーに期待される【行 動とスキル】ツールと戦略】が示されている(表 1). 状況に応じてこのツールを, 上手く活用す ることを多職種で訓練することで, チームで働 く力が身に付き，安全に実践できる.

この研修は, ゲーム形式のものやロールプレ イ,グループワークなどの多くの演習を通して, 参加者が気付き，知識を得て，実践に活かせる ように工夫されている.

\section{3. あなたのチームには誰がいますか？}

あなたは，今日，仕事で話した相手の名前と 職種を挙げられるだろうか? 自分がどのチーム
に存在して，チームには誰がいるのか承知して いるだろうか？毎日顔を合わせて患者の大事な 情報をやり取りし，自分が指示を出した相手の 名前が言えるだろうか? その後にどのような職 種が関わりどのような経路で患者に実施される か承知しているだろうか？実際には，なかなか 回答できない。この状況は, 他の職種も同様で ある.さらに，あなたのチームには患者と家族 が存在しているだろうか? “チームSTEPPS”で は「患者・家族を有益なパートナーである」3) と 考える. 名前や左右などの確認の協力, 必要な 情報の提示・共有をすることで副作用の出現な どの変化の通知, 治療の主体として患者・家族

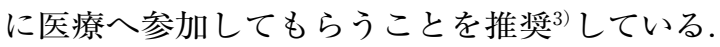
患者の声に耳を傾け，気がかりなことを聞き出 し，フィードバックをもらうことで，患者・家 族が間違いや見落としを早く知らせてくれるか もしれない.

図 2 「人生の網」演習 (チームSTEPPS教材と して国立保健医療科学院種田憲一郎氏が日本に 紹介したもの）では，職種はわかっていても， 
表 1. チームSTEPPSにおける 4 つのコンピテンシーとツール 5)

\begin{tabular}{|c|c|c|}
\hline チームワークコンピテンシー & 行動とスキル & ツールと戦略 \\
\hline $\begin{array}{l}\text { リーダーシップ } \\
\text { 指示や調整, 作業の割り当て, チーム } \\
\text { メンバーの動機付け, リソースのやり } \\
\text { 繰りを行い, チームのパーーマンスが } \\
\text { 最適になるように促進する能力 }\end{array}$ & $\begin{array}{l}\text { チームメンバーの役割を明確にする. } \\
\text { 期待されるパフォーマンスをす。. } \\
\text { チームのイベントを行う. チームの } \\
\text { 問題解決を促進する. }\end{array}$ & $\begin{array}{l}\cdot \text { ・リソースマネジメント } \\
\cdot \text { 権限の委譲 } \\
\cdot \text { ブリーフィング（打ち合わせ） } \\
\cdot \text { ハドル（途中協議, 相談) } \\
\cdot \text { デブリーフィング (振り返り) }\end{array}$ \\
\hline $\begin{array}{l}\text { 状況モニター } \\
\text { チームの置かれている状況・環境に対 } \\
\text { して共通の理解を発展させ，適切な戦 } \\
\text { 略を用してチームメイの分オーマ } \\
\text { ンスを正しくモニターし，共通のメン } \\
\text { タルモデルを維持する能力 }\end{array}$ & $\begin{array}{l}\text { チームメンバーの行動を相互モニ } \\
\text { ターし，お互いのニーズを予想し推 } \\
\text { 測する. 早めにフィードバックを行 } \\
\text { し, チームメンバーが自分自身で修 } \\
\text { 正することができる.セイフティー } \\
\text { ネットを構築する.お互しを気にか } \\
\text { ける. }\end{array}$ & $\begin{array}{l}\cdot \text { 状況認識 } \\
\cdot \text { 相互モニター } \\
\cdot \text { STEP } \\
\cdot \text { l'm Safeチェックリスト }\end{array}$ \\
\hline 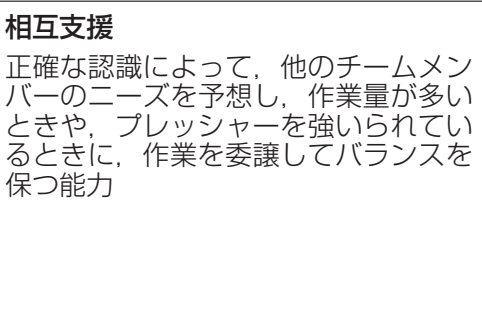 & $\begin{array}{l}\text { 活用できるチームメンバーに責任を } \\
\text { 委譲することにより作業配分の不具 } \\
\text { 合を修正する.建設的およ゙評価的 } \\
\text { なフィードバックを受けたり与えた } \\
\text { りする.対立を解決する.患者擁護 } \\
\text { や主張を行う. }\end{array}$ & $\begin{array}{l}\text { ·作業支援 } \\
\cdot \text { フィードバック } \\
\cdot \text { 患者擁護（アドボカシー）と主張 } \\
\text { (アサーシン) } \\
\cdot \text { ? 回チャレンジルール } \\
\cdot \text { CUS } \\
\cdot \text { DESC (デスク) スクリプト } \\
\cdot \text { 協働 }\end{array}$ \\
\hline $\begin{array}{l}\text { コミュニケーション } \\
\text { 手段に関係なく、チームメンバー間で } \\
\text { 情報を効果的に交換する能力 }\end{array}$ & $\begin{array}{l}\text { 定式化されたコミュニケーション技術 } \\
\text { こより, 重要な情報を伝える. 伝え } \\
\text { られた情報が理解されていることを, } \\
\text { 追加確認と承認を通して確かめる. }\end{array}$ & $\begin{array}{l}\cdot \text { SBAR（エスバ一） } \\
\cdot \text { コールアウト（声出し確認） } \\
\cdot \text { チェックバック (再確認) } \\
\cdot \text { ハンドオフ (引き継ぎ） } \\
\cdot \text { IPass the Baton (「バトンを手 } \\
\text { 渡します」) }\end{array}$ \\
\hline
\end{tabular}

(1)病院における医療安全を担保するために関わる職種・人物を 挙けナ゙る

(2)グループごとに各人が 1 つの職種を重ならないように選んで 輪になる（選んだ職種を付箋紙に記入しネームバッジに添付）

(3)グループ内からー人選ぶ「○○からスタート」

○役の方はヒモの端を持って, 医療安全担保のために協力 する必要がある他の職種を選びヒモの端を持ったまま選んだ 相手にヒモを渡す。この時選んだ理由を述べる。

「患者の安全を守るために・.」

(4)(3)でヒモを渡された役の方は次の 職種を選んで理由を添えてヒモを 持ったまま相手にヒモ渡す

(5)(4)を繰り返す

(6)選ぶ職種が出てこなくなつたら修了

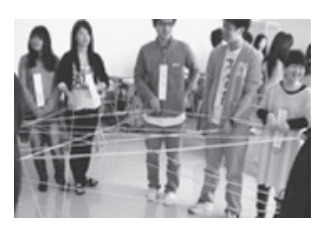

図 2. Web of Life（人生の網） 


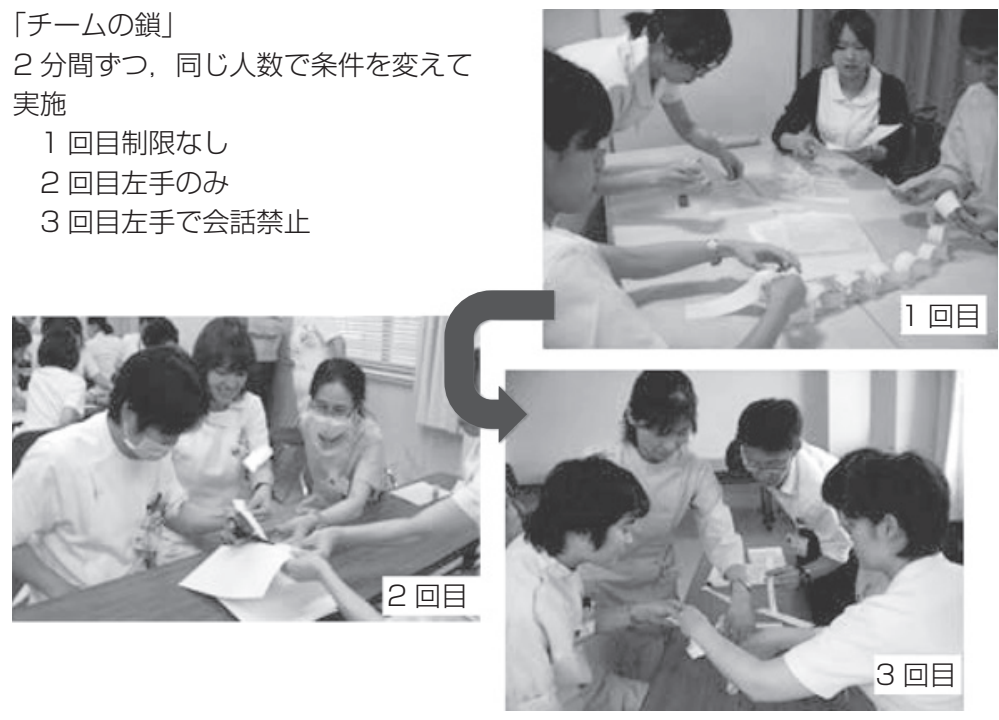

図 3. チームの鎖

どんな業務をしているのか, チーム医療の中で どのような役割があるのか理解していないため, 患者の安全を守るため相手に何を期待したらい いのか伝えられないことを痛感させられる．医 療事故が起こると「自分はもっとこうしたい」「相 手にはもっとこうしてほしい」と要望できるが, 本来は，事前に様々なことを予測してお互いに どうしたら安全にできるか打ち合わせ，いつで もそうできるように備えておく必要がある。

医療安全は，よくチームスポーツに例えられ る. 例えば, サッカーで同じチームにいながら, お互いに名前もポジションも知らず，そのポジ ションの役割も知らない, みんなで何を目指し お互いに何を期待するのか前もって考えたこと がない，集まって練習したこともないチームな ど存在するだろうか?

\section{4. チームパフォーマンスを高めるカと} は?

“チームSTEPPS”では，チームパフォーマン スを高める 4 つコンピテンシーがあり, この
4 つは相互に関連し,多職種で訓練し実践で活用 することでパフォーマンスが向上するとされて いる ${ }^{3)}$.この 4 つのコンピテンシーを理解するた めに「チームの鎖」) (図 3) という演習を行って いる. この演習では，チームで協力し紙を切っ て作った短冊に糊をつけて輪を作り, さらに鎖 状に繋げる作業を行い, 繋がった輪の数を競う. 同じ人数, 同じ道具, 同じ時間で作業するにも かかわらず，各グループでかなりパフォーマン スが違ってくる，表 2 は, ある研修の演習結果 である。

$7 \mathrm{G}$ では, 会話ができて両手が使えた 1 回目よ りも会話禁止で左手だけで行った 3 回目の方が より多くの輪の繋がった鎖を作れているなど, 多くのチームが 3 回目のパフォーマンスが高く なっている. その理由の 1 つとして, 1 回目, 2 回目で上手くできたことや上手くできなかった ことを振り返りや打ち合わせすることによって 活かし, チームで継続して改善に取り組んだ成 果が 3 回目の結果として出ていると考えられる. より厳しい状況下でも, チームとして上手く機 能すればよい結果が得られる。チームの中に, 
表 2.「チームの鎖」演習結果

\begin{tabular}{c|c|c|c|c}
\hline & $\begin{array}{c}1 \text { 回目 } \\
\text { (制限なし) }\end{array}$ & $\begin{array}{c}2 \text { 回目 } \\
\text { (左手のみ会話OK) }\end{array}$ & $\begin{array}{c}3 \text { 回目 } \\
\text { (左手のみ会話禁止) }\end{array}$ & $\begin{array}{c}2 \text { 回目亡 } 3 \text { 回目 } \\
\text { の比較 }\end{array}$ \\
\hline $1 G$ & 35 & 15 & 24 & $\uparrow$ \\
$2 G$ & 41 & 12 & 11 & $\downarrow$ \\
$3 G$ & 35 & 14 & 14 & $\uparrow$ \\
$4 G$ & 38 & 5 & 12 & $\uparrow$ \\
$5 G$ & 23 & 6 & 9 & $\uparrow$ \\
$6 G$ & 31 & 4 & 16 & $\uparrow$ \\
$7 G$ & 8 & 13 & 16 & $\uparrow$ \\
$8 G$ & 32 & 4 & 16 & $\uparrow$ \\
\hline
\end{tabular}

この演習の経験者や両手が使いこなせる人（左 手作業の際には利き手ではない手を使っていた だく）がいるほうが有利に見えるが，実際には あまり結果に影響しないことが多い。また，看 護部長や看護師長，医療安全管理者，主任医長 などの管理者だらけのチームが，かえって上手 くいかないこともあった. 逆に, 学生だけのチー ムでは，50 個くらい簡単につなげてしまう。一 部の優秀な誰かに頼るより, チームとして働け る人の集団のほうがパフォーマンスは高いとい う現象を目の当たりにする。

チームパフォーマンスに影響する重要な前提 として,チーム全員の「メンタルモデルの共有」3) が必要である。この演習の目標は, 誰にでもわ かりやすい. 知識も技術も十分でない学生でも, 全員が何を目指すのか共通理解し（メンタルモ デルの共有), 声を掛け合いながら(コミュニケー ション), 周りをよく見て状況を認識し, 状況に 応じてそれぞれがリーダーとして対応し，お互 いを気にかけ，相手のニーズや自分の作業の困 難さを認識し(状況モニター), 支援を要請した り申し出たりするバックアップ行動 (相互支援) を行うことで, 高いパフォーマンスが維持でき る. ここに, メンバーの潜在能力を引き出し, 全体を見て現状把握し, 次に何が起こるか子予測 し, 情報を集めて何が必要か判断し, 工夫しな がらタイミングよくチームをガイドするリーダー
シップが加わればさらによくなるであろう。

この演習では, 条件を変えて作業を繰り返す. パフォーマンスが高かったチームは,「積み重ね でチームが上手くなった」と，チーム活動を繰 り返し, 関係づくりを行うプロセスの重要性を 語った。一方, 上手くいかないチームは, メン タルモデルを共有しておらず, 周囲の状況やチー ムを認識していない。通常の仕事でも同じよう なことが起きていないだろうか?

例えば,

・ハサミを持つと紙を切り続け，たくさんの 短冊のごみを出すチームがいる。普段も, 限ら れた時間を上手く使わず(状況モニター)，無駄 な作業をしていないだろうか?

・「私はきれいに作りたい」と時間をかけてし まう人がいる，チームで目指す目標はきれいに ではなく，多くつなげることである．普段も， チームにとって優先すべきことではなく，個人 のやりたいことにこだわり過ぎて，メンバーが メンタルモデルを共有できていない状況がない だろうか?

・左手の作業では一人で上手くできないのに, 支援を求めず頑張ってしまう人がいる. 普段も, 誰かと助け合えば(相互支援), 簡単に早く安全 にできる作業を一人で無理に行っていないだろ うか?

・他のメンバーが状況を目の前で見ていても, 
それぞれが自分の作業だけに集中しすぎて周囲 が見えない，もしくは見えていても，少し污く ても早く切ろう, もう切るのをやめよう, 手伝 います，手伝ってくださいと声をかけることが できていない. 普段も, チームを意識してお互 いを見て（状況モニター）協力し合い（相互支 援), どうしたらもっとよりよくできるか考えな がら会話(コミュニケーション), 行動できてい るだろうか?

・リーダーが, メンバーの仕事に常に指示を 出しすぎると, メンバーは自分の考えや行動に 自信を無くし，指示が出るまで手を止めてしま い, 結果として時間だけが過ぎる，普段も強す ぎるリーダーシップによって，メンバーの個人 の能力を活かせない状況を作っていないだろう か?

•3 回の作業の間に時間を上手く使って, 次に 活かすために打ち合わせするチームとそうでな いチームがいる。普段も, チームで働くために 仕事の中に打ち合わせ（リーダーシップ）をす る時間を設けているだろうか？

チームが機能するために重要なのは, 一人二 人の優れた人を抱えることではない. チームで 一丸となって協働できる力を育むことである. この演習は, チームパフォーマンスを向上させ るために必要な力に気づき実感できるトレーニ ングとして期待できる.

5. あなたは, チームの危機を救う「声」に 耳を傾け，応えていますか?

看護師は, 患者の変化に気付き医師や多職種 に伝える発信者であり, 医師の指示を直接受け, 様々な職種と関わりながら実践するプロセスの 最終実施者である。患者の状況を観察し, 医師 に報告し指示を受け，正しく実施することが求 められる. しかし, この報告や指示が上手く伝 わらないために発生した医療事故やヒヤリハッ
ト報告を経験された医師も多いであろう。

481 床の総合病院で職員にアンケートした結果 （図 4) は, 急変時のDrコールが上手く伝わらな かった経験について割合を示している。一部の 看護師には「状況と背景のみを伝えれば医師は 当然状況をわかってくれて駆けつけてくれるだ ろう」と考え, 明らかな急変時でも「すぐ来て ほしい」提案ができない者もいる．医師から「看 護師のアセスメントはいらない」「診察するかど うかは自分で決める」というような否定的な発 言や軽視されたあるいは無視されたと感じてし まうような態度を受けた経験をすることによっ て, 自信や経験がないことはアセスメントや提 案をしない傾向もあると考える.また,「報告し たが医師に上手く伝わらず“様子をみて”と言 われた。 そう言われると安心し危機感が薄れ, その後の報告が遅れた」という意見もあり，普 段よく使う「様子を見る」も，ケースによって はリスクが高い状況になる恐れもある.

また，「看護師の “なんか変” “重大な事態” と いう焦り具合だけで，緊急性は伝わる」という 傾向が経験 18 年目以上の医師に多いことや, 多 くの看護師が「気になる患者がいるときには前 もって起こりうる状況やどの状況でコールした 方がよいか医師に確認しておく」など，経験を 重ねて対応してきた．どうしたらもっとうまく 伝えられるかは, 多くの看護師にとって共通の 課題である.

最近, 多くの看護職が医師への報告のツール として「SBAR」5) (図 5) を使用することが多く なってきた.さらに, 1 回伝えても伝わらない時 には少なくとももう一度報告する「2 回チャレン ジルール」5)や, 自分が感じた懸念や疑義を具体 的に伝える「CUS」5) (図 6) を使って, 自分が気 づいた患者の大事な情報を医師に伝える手段を 持つようになってきた.

しかし，このツールは看護師だけが理解し使 用しても活かされない. ツールだけ導入しよう 
＜急変時のDr コールについて $>$

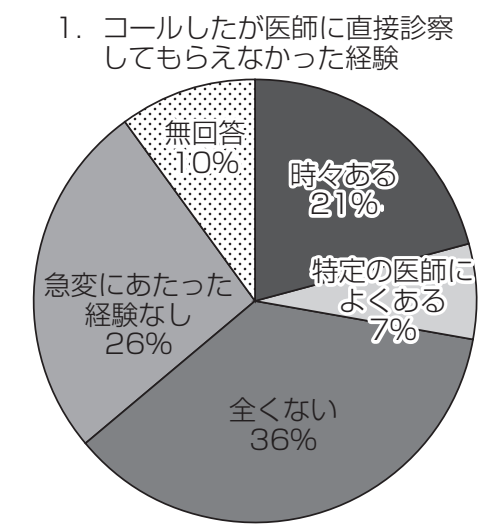

看護師 $(n=350)$ と多職種 $(n=247)$
2. 多職種にコールされたが緊急性の 判断ができなかつた経験

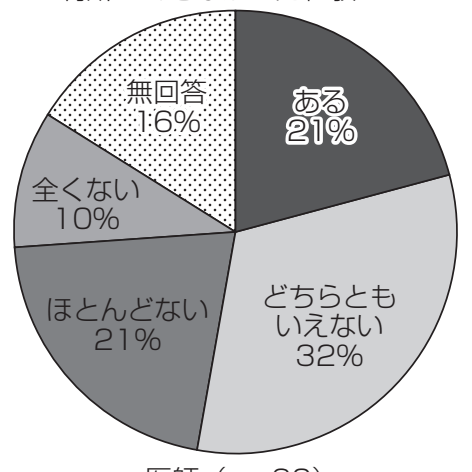

医師 $(n=60)$

3.「緊急」なのか「相談」なのか「報告」なのかはっきり伝えている

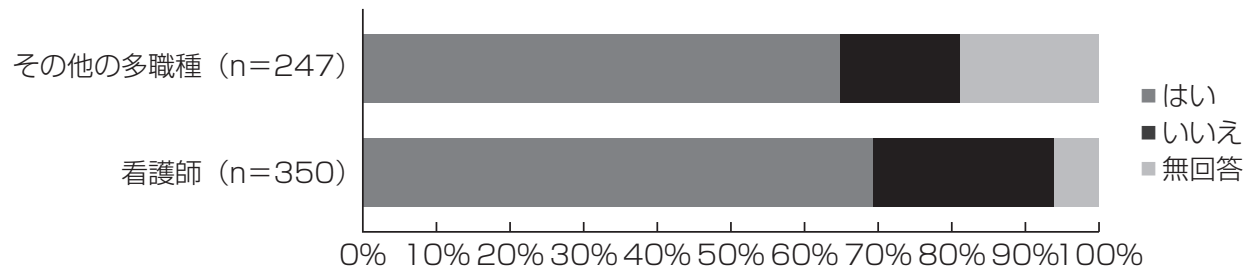

4. 明らかに急変で医師に現場に駆けつけて欲しい場合 「急変です.すぐ来てください.」と言う

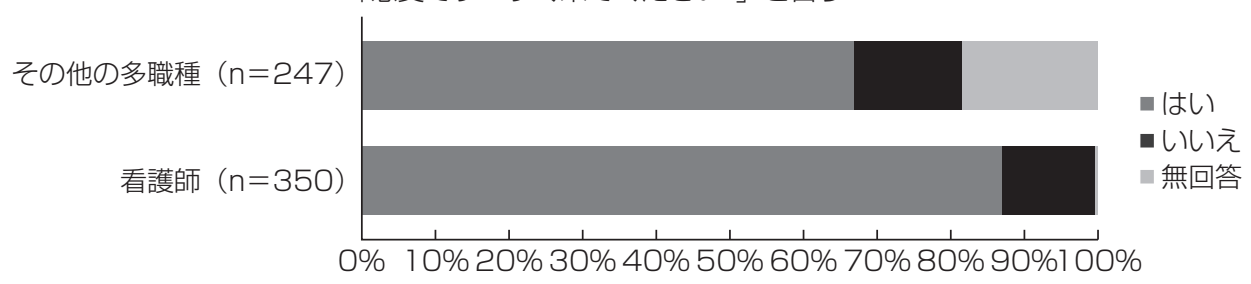

図 4. 総合病院 (481 床)

医師 · 看護師 · その他の多職種対象のコミュニケーションに関するアンケートの結果

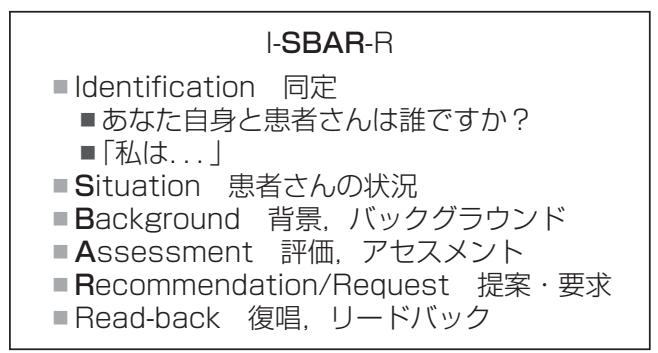

図 5. コミュニケーションツール「SBAR」5) AHQR, 国立保健医療科学院訳 : ポケットガイド チームSTEPPS引用

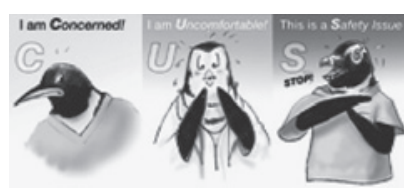

段階に応じて主張の度合いを強めていく方法

\begin{tabular}{lll} 
I am & Concerned & 気になります 心配です \\
\hline I am & Uncomfortable & 不安です \\
\hline This is a & Safe Issue & 安全の問題です \\
& 中断してください
\end{tabular}

図 6. コミュニケーションツール「CUS」5)

AHQR, 国立保健医療科学院訳 : ポケットガイド チームSTEPPS引用 


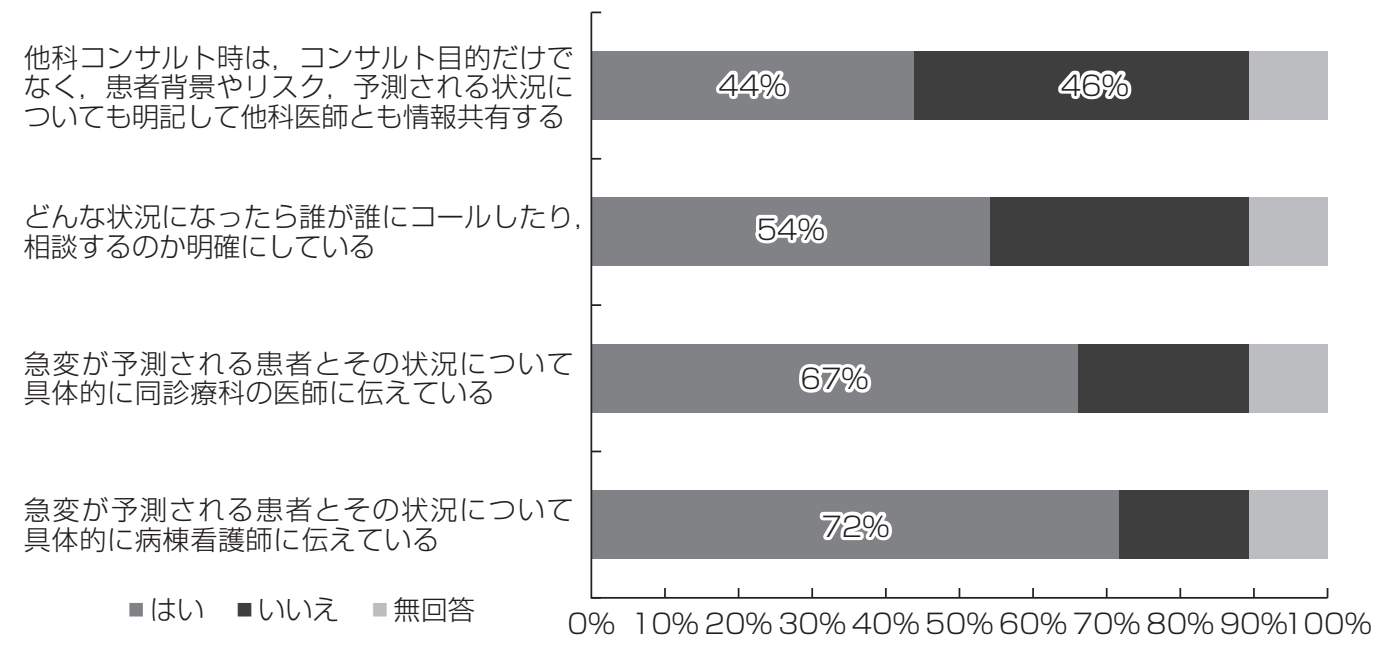

図 7. 総合病院 (481 床) の 10 病棟に調査した

医師が行っている「医師一医師間」「医師-看護師間」の情報共有について

としても上手くいかない. 医師も他職種もチー ムで取り組み, このツールの意味するものを理 解し受け止めて, はじめて成立する. 看護師の 「何かおかしい」「いつもと違う」という感覚は, 根拠のない「感情論」に聞こえるかもしれない. 前述したアンケートでも, 状況を伝えたい看護 師と結論や要求を知りたい医師とのニーズの違 いを問題視する意見もあった. しかし，看護師 の相談・報告は「患者が助けを求める声」でも ある.「報告」によって, 知識を深めることやミ スの未然防止, 自分の気付かないポイントの発 見，チームの一員としての認識などを学習でき るチャンスとなる。「報告」時, 看護師の観察や アセスメントに間違いや問題があっても,「報告」 してきたことには「よく報告してくれたね，あ りがとう」と感謝し，次回は上手くできるよう に具体的にアドバイスし，成長できるような指 導の場にしていただきたい。看護師の成長を， 同じチームの一員として気にかけてほしい.

看護師は, 他の職種よりも患者のそばにいて 様々な経験を持つ複数でケアをしている強みが ある。同じチームの一員として，その患者の病 状や治療の方向性に関する医師の考えを看護師
に伝え共通認識すれば，医師が判断するのに必 要なことを予測し，適切な情報・フィードバッ クを医師に提供できる．指示を出す時や変更す る時は, その目的や理由を添えていただきたい. その情報を受けた者は，医師に代わってうまく 対応し, 自分の役割・責任を理解し, 個人のパ フォーマンスを向上させてチームの一員として 力を発揮するはずである.

さらに，医師同士，医師と看護師間の情報共 有（図 7)の結果を見ても分かるように, リスク に関する情報共有に問題がある。その患者のリ スクに対応できる適切な引き継ぎができる「I PASS the BATON 」5)を活用することでより安全 になる。

私たち看護師は, チームの中で最も多く患者 に接している. 患者の安全が危険にさらされて いるとき, 看護師の声は, チームを動かす, あ るいはチームを止める「情報」になり，チーム の危機を救い, チームが患者安全の方向に動く ことに大きく影響する。誰かの声「報告」を受 け入れてチームが動くことで, 世界（誰かの運 命・自分の運命）が変わるかもしれない. 


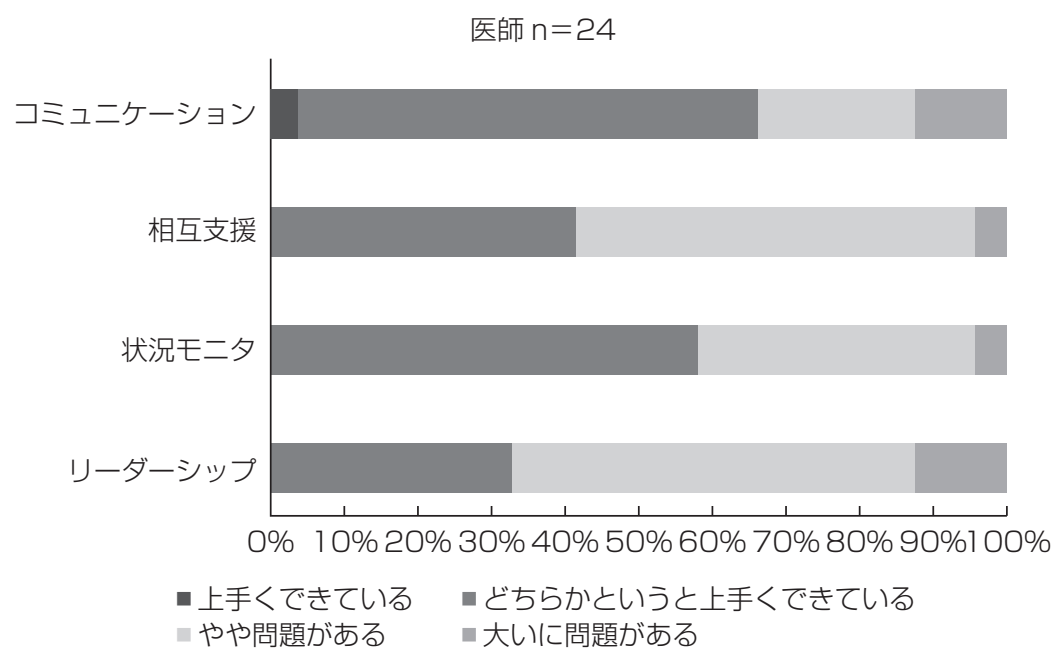

図 8. チームSTEPPS研修参加後のアンケート

\section{6. チームとして機能するために医師に期} 待する力は?

“チームSTEPPS”で示されている 4 つのコン ピテンシーの中で, 医師に最も期待したいこと は「リーダーシップ」である，研修の中で，よ いリーダーとは? というグループワークを通し て他職種から語られる医師への期待は, 話を聞 いてくれる人, チームの問題として共通理解し ようとしてくれる（わかってくれる，認めてく れる, 当事者意識がある), カンファレンスなど の話し合いの場で話をまとめる, 成果を示し結 論を明確にできる，チームの方向性を示してく れる，決定に責任を持つなどである.メンバー が達成感を得られる仕事をさせてくれる人（価 值ある仕事をさせてくれる）という，チームと して働くことのやりがいに関する意見も多い. 私は, 研修後に参加者に 4 つのコンピテンシー について 4 段階で自己評価をしていただいてい る.どの職種でも共通して評価が低いのが「リー ダーシップ」であり, 医師もその評価は低い(図 8). 医師が、リーダーとして上手く役割を果た
せないことの理由の 1 つには, リーダーシップ やチームとしての協働の仕方について学ぶ機会 (チームトレーニング)が少ないことが挙げられ る. 学ばずしてチームとして協㗢することは困 難である。“チームSTEPPS”などチームトレー ニングについて学ぶ機会があれば, 医師も他職 種と一緒に積極的に参加していただきたい.

そして、リーダーシップを上手く発揮するた めに, リーダーがチームをまとめる 3 つの打ち 合わせ「ブリーフィング (打ち合わせ)」「ハドル (途中協議)」「デブリーフィング(振り返り)」5)を 活用してほしい. 打ち合わせで, チームの目標 や気を付けるべき点を共通理解し, 役割を決め る.医師がいると他の職種は黙って指示を聞く だけになってしまうことがある．そんなときに 医師にお願いしたいことは, 誰（名前）に何を してもらいたいのか具体的に指示することと, 自分の指示が相手に伝わったかどうか確認する ことである.「復唱(リードバック), 再確認(チェッ クバック）」5)などがある.看護師が何度も確認す ることを嫌う医師もいるが, 大事な情報が伝わっ ていないか，もしくは疑義や懸念というリスク の高い状況である場合が多い，看護師や薬鼡師 
等の「確認の声」を遮らないでほしい.むしろ, 安全行動ができていると良い評価を与えてもら いたい. そして, 打ち合わせの最後に, 医師か らメンバーに, 気になること, 心配なこと, 確 認したいこと, 提案がないか尋ねてほしい. そ うすると, メンバーは気兼ねなく, 専門職とし ての発言や安全確認がしやすくなる.

活動終了後の「デブリーフィング」桌は, チー ムワークスキル向上と結果の改善のためによ かったことと改善すべきことを振り返り，チー ムの成長を実感し，次につなげる重要な場であ る.

医師は，その専門性からリーダーの役割を期 待されることが多いが, 状況によってはその役 割を代わってもらう, 助けてもらう判断も必要 である。また，わからないことや迷い，不安を 人には言えないと考える医師もいるかもしれな い.しかし, 「疑問」は自分やチームの判断を見 直す絶好のチャンスでもある.「わからない」「迷つ ている」と声に出す, 判断に困ったら, すぐ決 めない, 1 人で決めない, 1 人で何とかしようと しない, 弱者の立場で個人やチームで再検討 (ハ ドル）する。研修後のアンケートに「自分でや る方が早いと思い, 相談も情報共有もしなかっ たが，それでは，自分のミスにも気付かず，自 分も相手も成長せず, 視野も広がらない。相手 を信じて受け入れることの重要性に気付いた」と 記載があった．少なくとも看護師長やリーダー 看護師は，役割を代わることが可能であろう.

チームは, お互いに助け合い, 補い合うこと で目標が達成される。状況や場面に応じて医師 以外の他職種にリーダーシップをとってもらい, 医師は良きフォロワーシップを発揮し，チーム を支えてほしい.「助けを求めることはできない, 信頼されなくなってしまう，弱みを見せられな い」と思う医師もいるだろうが，むしろ逆であ る. 価值ある仕事を任されたメンバーは, 自分 を頼ってくれたことを誇りに思い, 助けたい,
力になりたい，役に立ちたいと考える、役割を 果たした経験がチームとして誰かのために役立 てた充実感と誇らしさ，みんなで何かをすると いう一体感を味わう機会となり，成長にもつな がる.

\section{おわりに}

医師は，組織の中の 1 つのチーム医療の一員 (あなたはひとりではない)であることを意識し, その職種や人の特徴を把握, 理解, チームが持 つ強みを活かし，自分と相手を信じ，受け入れ， 共に活動してほしい. 何かあったときに, 上手 く対応できるチームになるには, 日頃からの風 通しのよい信頼関係を築いておくことこそが一 番の近道かもしれない. 挨拶や何気ない会話で 自分自身のこと（大切にしている医療への思い, 仕事の流れ等）を相手に理解してもらうことも 大事である。人の思いが人を動かす。チームト レーニングに積極的に参加し, チームとして協 働するためのスキルを身に付けた医師がいきい きと活動する安全なチームが増えることが期待 される。

研修で使用するチーム活動場面動画（チーム STEPPS教材) は, 米国のもので, 医師の笑顔と タッチングと「Good job!」の言葉でしめくられ ている.日本人には馴染まないかもしれないが, 医師の笑顔とタッチングと集め言葉は, チーム に心地よい空間を与えてくれるであろう。

著者のCOI (conflicts of interest) 開示 : 本論文発表内容に 関連して特に申告なし

\section{文献}

1) TeamSTEPPS ${ }^{\circledR}$ : National Implementation. Agency for Healthcare Research and Quality. http://teamstepps.ah rq.gov/

2）種田憲一郎：診療の安全と質を向上させるッール. 日内 会誌 $100: 226-235,2011$.

3）種田憲一郎：チーム医療とは何ですか? 何ができるとよ 
いですか?一チームSTEPPS : エビデンスに基づいたチー ムトレーニングー. 医療の質・安全学会誌 $7: 430-441$, 2012.

4）種田憲一郎：チーム医療とは何ですか?一エビデンスに 基づいたチームトレーニング : チームSTEPPS-. Medical forum CHUGAI $14(1 \sim 4): 2013$.

5）国立保健医療科学院訳 : チームSTEPPSポケットガイドー 06.1（日本語版 8.1）. AHRQ Pub, 2014, No6-0020-2.

\section{参考文献}

1）種田憲一郎：チームとしてのよりよいパフォーマンスと 患者安全を高めるためのツールと戦略. 医療安全 24 : 38-44, 2010.

2）Reid J, 他：「声がけ」がチームを救う：医療現場にヒュー マン・ファクターズが必要な理由. 医療の質・安全学会 誌 $7: 332-347,2012$. 